\title{
Supplementation of Low Cost Alternative Foods to Combat Vitamin C Deficiencies among Children
}

\author{
Mouneshwari R. Kammar and S. Vanishree*
}

ICAR-Krishi Vigyan Kendra, Bagalkot, UAS Dharwad and Assistant professor, Home Science, Agriculture Extension Education Centre, Lingasugur, UAS Raichur, India

*Corresponding author

\begin{tabular}{l} 
Ke y w o r d s \\
$\begin{array}{l}\text { Vitamin, } \\
\text { Supplementation, On } \\
\text { farm testing, Collagen, } \\
\text { Health status }\end{array}$ \\
\hline Article Info \\
\hline $\begin{array}{l}\text { Accepted: } \\
\text { 22 July } 2018 \\
\text { Available Online: } \\
\text { 10 August } 2018\end{array}$ \\
\hline
\end{tabular}

\section{A B S T R A C T}

An On farm testing on supplementation of Vitamin $\mathrm{C}$ rich foods to combat Vitamin C deficiencies among school children was carried out in Raichur taluka during the year 201314. The aim of this testing was to supplement low cost alternative to combat vitamin ' $\mathrm{C}$ ' deficiency among and children. Forty five children from three Government Primary schools of Raichur taluka were selected purposively for this study. The diagnostic features of vitamin deficiency were gum bleeding, delayed wound healing, infections and split hair. The foods which are rich in vitamin C and dose as recommended by NIN Hyderabad were supplemented. The nutrition supplementation was carried out for three months during January to March 2014.The checklist was administered before and after the supplementation. Qualitative observations on the deficiency symptoms of vitamin C and the perception about health status were also recorded. Though all the foods were accepted by the children, amla was most effective in reducing the symptoms of vitamin c deficiency. But the availability of amla and quantity to be consumed were the constraints faced by the researcher. On the other hand, lime juice and guava were most relished by all the children.

\section{Introduction}

Vitamin $\mathrm{C}$ or ascorbic acid is an essential dietary nutrient for a variety of biological functions which found in many of fresh fruits and vegetables. It helps the body to make collagen, an important protein used to make skin, cartilage, tendons, ligaments and blood vessels. Vitamin $\mathrm{C}$ is needed for healing of wounds and repairing and maintaining bones and teeth. Vitamin $\mathrm{C}$ certainly places an important role in immune function and it removes free radical intermediates that initiate damaging cell reactions (Andea and Brakhuis, 2012). Deficiency of vitamin C may cause inflammation of gums, bleeding of gums, decreased wound healing rate, decreased ability to ward off infection and splitting of hair.

Though most animals are able to synthesize endogenously but humans do not have capability to synthesize vitamin $\mathrm{C}$, however requirement of vitamin $\mathrm{C}$ is satisfied by consumption of natural sources i.e fruits and vegetables. In this regard an OFT (On Farm 
Testing) on supplementation of vitamin $\mathrm{C}$ rich foods to combat vitamin $\mathrm{C}$ deficiency among school children was conducted.

\section{Materials and Methods}

Present study was conducted in three different school of Raichur District during the year 2013 - 14. Purposive sampling was made to select 15 children studying in $6-9^{\text {th }}$ standard from each school, which possessed one or more vitamin $\mathrm{C}$ deficiency symptoms were identified. Thus total sample was 45. Care was also taken to match the socio-economic status of the children in different treatments.

Locally available three vitamin $\mathrm{C}$ rich foods were selected viz., Amla, Guava and Lime to supplement selected children. Each type of fruit was provided to each school children. The dosage was followed as per the recommendations of NIN (National Institute of Nutrition), Hyderabad

$\mathrm{T}_{1}$ - Amla fruits, $20 \mathrm{~g} / \mathrm{day} / \mathrm{head}$

$\mathrm{T}_{2}$ - Guava fruits, $50 \mathrm{~g} /$ day/head

$\mathrm{T}_{3}$ - Lime juice, $30 \mathrm{~g}$ lime and $15 \mathrm{~g}$ sugar/day/head

These supplementations were given for selected children over a period of 3 months, i.e January to March. The pre-structured questionnaire was administered to the respondents before and after supplementation of vitamin $\mathrm{C}$ rich foods. Qualitative observations were made on the deficiency of symptoms of Vitamin C and perception about health status was also recorded.

\section{Results and Discussion}

After the supplementation of vitamin $\mathrm{C}$ rich foods for a period of three months, following observations were recorded by comparing with control group of children and also their opinion before and after supplementation.

Among the selected foods Amla contain higher amount of Vitamin C (600mg) followed by guava (212mg) and lime (63mg). Similarly the quantity of fruits supplemented were only $20 \mathrm{~g}$ of Amla, $50 \mathrm{~g}$ of Guava and $30 \mathrm{~g}$ of lime. It can be observed that cent per cent RDA was met in case of Amla and Guava whereas, 40 per cent met by lime as depicted in Table 1.

Values in the parenthesis indicate percentages

It is inferred from the Table 2 that, diagnostic feature of Vitamin $\mathrm{C}$ deficiency shows about 73-80 per cent of children were suffering from the incidence of bleeding of gums before supplementation, whereas children supplemented with amla showed better recovery $(13.33 \%)$ followed by the children supplemented with Guava (26.66 \%)and Lime juice $(54.54 \%)$.

This may be due to the reason that amla contain higher proportion of vitamin $\mathrm{C}$ compared to Guava and Lime. With regard to incidence of infection, it was noticed that lesser per cent of children showed infections in selected children i.e., around 13 to 26 percent before supplementation,

However, after supplementation there was no infection was observed in children supplemented with Amla and negligible per cent of children expressed infection in case of children supplemented with Guava (6.66\%) and Lime (6.66\%). Anti-bacterial as well as astringent characteristics of Indian gooseberries safeguard the entire body from infections and increases body's immune reaction. Amla fruit has antiviral properties and also functions as an anti-bacterial and anti-fungal agent (Srivasuki, 2012). 
Table.1 RDA for Vitamin C for children (10-14yrs) and vitamin C composition in selected foods

\begin{tabular}{|l|c|c|c|c|}
\hline $\begin{array}{l}\text { Selected } \\
\text { fruits }\end{array}$ & $\begin{array}{l}\text { Vitamin C } \\
(\mathbf{m g} / \mathbf{1 0 0} \mathrm{g})\end{array}$ & $\begin{array}{l}\text { RDA for Vit C } \\
(\mathbf{1 0}-\mathbf{1 4} \mathbf{y r} \text { children) }\end{array}$ & $\begin{array}{l}\text { Supplemented } \\
\text { qty }(\mathbf{g})\end{array}$ & $\begin{array}{l}\text { \% of Vitamin C } \\
\text { requirement met }\end{array}$ \\
\hline Amla & 600 & $45 \mathrm{mg} /$ day & $20 \mathrm{~g}$ & 100 \\
\hline Guava & 212 & $45 \mathrm{mg} /$ day & $50 \mathrm{~g}$ & 100 \\
\hline Lime & 63 & $45 \mathrm{mg} /$ day & $30 \mathrm{~g}+15 \mathrm{~g}$ sugar & 40 \\
\hline
\end{tabular}

Table.2 Qualitative observations before and after supplementation

\begin{tabular}{|l|c|c|c|c|}
\hline \multirow{2}{*}{ Children groups } & \multicolumn{2}{|l|}{ Incidence of gum bleeding } & \multicolumn{2}{l|}{ Incidence of infection } \\
\cline { 2 - 5 } & Pre test & Post test & Pre test & Post test \\
\hline Amla group & $11(73.33)$ & $2(13.33)$ & $2(13.33)$ & 0 \\
\hline Guava group & $12(80.00)$ & $4(26.66)$ & $4(26.66)$ & $1(6.66)$ \\
\hline Lime group & $11(73.33)$ & $6(54.54)$ & $4(26.66)$ & $1(6.66)$ \\
\hline
\end{tabular}

Table.3 Cost of fruits selected for supplementation/day

\begin{tabular}{|l|c|c|c|}
\hline $\begin{array}{l}\text { Selected } \\
\text { fruits }\end{array}$ & $\begin{array}{c}\text { Supplemented Qty } \\
(\mathrm{g})\end{array}$ & $\begin{array}{c}\text { Cost of fruits } \\
(\mathrm{Rs} / \mathrm{kg})\end{array}$ & $\begin{array}{c}\text { Per head/day expenditure } \\
(\mathbf{R s})\end{array}$ \\
\hline Amla & 20 & 60 & 1.20 \\
\hline Guava & 50 & 62 & 3.72 \\
\hline Lime & 30 & 40 & 1.8 \\
\hline
\end{tabular}

Cost of selected fruits for supplementation to children depicts that amla was found to be low cost with good out come in posttest followed by lime juice, however cost of guava fruit found to be comparatively little higher as shown in Table 3.

Inclusion of Vitamin $\mathrm{C}$ rich foods in regular diet may greatly help to reduce the deficiency symptoms of Vitamin C viz., bleeding of gums and infections which in turn help to develop natural immunity and better iron absorption. Though all the foods were accepted by children, amla was most effective, however availability of amla and quantity to be consumed were the constraints faced by the researcher. On the other hand lime juice was most relished by all the children and even guava too. With this study we can recommend vitamin $\mathrm{C}$ rich foods especially amla in mid-day meal programme either as fresh or processed to reduce infections which are very much common for children. Even schools can plan to have nutrition gardens in the school premises which fetches no cost for supplementation.

\section{References}

Andrea, J. and Braakhuis, 2012, Effect of vit C supplements on physical performance. Current sports medicine medicine, 11(4): 180-183.

Grosso, G., Bei, R., Mistretta, A., Marventano, S., Calabrese, G., Masuelli, L., Giganti, M. G., Modesti, A., Galvano, F. and Gazzolo, D., 2013, Effects of vitamin $\mathrm{C}$ on health: A review of evidence. Front Bioscience, 1(18): 1-16.

Joseph and Minipriya, R., 2011, Nutritional, medicinal and pharmacological 
properties of guava. International Journal of Pharma and Biosciences, 2(1): 53-69.

Saini, S. and Kundal, A., 2015, Vitamin C content in locally available vegetables and fruits of retail shop in District kurukshetra. Indian J. of Sci. Res., 10(1):58-62.

Srivasuki, K. P., 2012, Nutritional and health care benefits of amla. Journal of Pharmocognosy, 3(2):147-151.

\section{How to cite this article:}

Mouneshwari R. Kammar and Vanishree, S. 2018. Supplementation of Low Cost Alternative Foods to Combat Vitamin C Deficiencies among Children. Int.J.Curr.Microbiol.App.Sci. 7(08): 4143-4146. doi: https://doi.org/10.20546/ijcmas.2018.708.432 